\title{
Efek Pemberian Temu Putih (Curcuma zedoaria) terhadap Kualitas Susu Sapi Perah Penderita Mastitis Subklinis
}

\section{Effect of Curcuma Zedoaria on milk composition of sub-clinical mastitis dairy cow}

\author{
H. Susanty dan E. Nurdin \\ Fakultas Peternakan Universitas Andalas, Kampus Unand Limau Manis 25163 \\ e-mail: hildasusanty@gmail.com
}

(Diterima: 1 Februari 2012; Disetujui: 30 April 2012)

\begin{abstract}
An experiment was conducted to evaluate the effect of Curcuma Zedoaria on milk composition of sub-clinical mastitis dairy cow. Concentrate was prepared by mixing level of curcuma zedoaria powder. Nine heads of sub-clinical mastitis dairy cows were divided into three groups. The first group were as a control, the second group were treated with $0.02 \%$ of Curcuma zedoaria according to body weight, and likewise the third group were treated $0.04 \%$ of Curcuma zedoaria. Data were analyzed with Variance analysis in a completely randomized design. The result showed that there were no significant effect of using different levels of Curcuma Zeoaria. The quality of milk in term of fat, protein, dry matter were satisfied for the quality standard of milk.
\end{abstract}

Keywords: milk, Curcuma zedoaria, sub-clinical mastitis

\section{PENDAHULUAN}

Penyakit radang ambing yang dikenal sebagai mastitis masih tetap merupakan masalah utama peternakan sapi perah, karena menyebabkan kerugian yang cukup besar sehubungan dengan penurunan produksi dan kualitas susu, penyingkiran susu, biaya perawatan dan pengobatan yang cukup tinggi, serta pengafkiran ternak lebih awal.

Infeksi atau peradangan ambing dapat mempengaruhi komposisi air susu. Infeksi oleh bakteri patogen penyebab mastitis menyebabkan kerusakan sel sekretoris ambing dan menurunkan kemampuan sintesa laktosa, kasein, lemak dan protein, dilain pihak serum albumin atau protein whey dan $\mathrm{pH}$ susu akan mengalami peningkatan (Hurley 2009, Jones 2009).

Pengobatan mastitis umumnya menggunakan antibiotik secara intramammae. Dalam usaha mencapai produksi semaksimal mungkin, seringkali penggunaan antibiotik ini tidak memperhatikan aturan pakai yang benar. Disamping kontrol terhadap pelarangan penjualan susu yang mengandung residu antibiotik sangat sulit dilakukan. Tindakan tersebut telah memperbesar peluang terdapatnya residu antibiotik dalam produk peternakan (Langford et al. 2003).

Tanaman obat umumnya mengandung senyawa antioksidan, antibakteri dan antiinflamasi. Kombinasi senyawa tersebut diperkirakan sangat baik digunakan untuk meningkatkan daya tahan tubuh ternak sekaligus mengurangi peradangan yang sering menyertai mastitis pada ternak (Shem et al. 2000, Nurdin 2006, 2007).

Salah satu tanaman obat yang diperkirakan dapat dimanfaatkan untuk meningkatan daya tahan tubuh ternak adalah temu putih (Curcuma zedoaria (berg.) Roscoe). Rimpang temu putih mengandung minyak atsiri yang terdiri dari senyawasenyawa flavonoid, seskuiterpen yang terdiri atas: zedoarone, kurdiona, epikurkumenol, kurzerena, kurkumol dan isokurkumenol. Zatzat ini berfungsi sebagai antiinflamasi, analgetik hepatoprotektor dan antioksidan. Selain fungsi tersebut flavonoid dan 
seskuiterpen juga bermanfaat untuk meningkatkan imunitas dengan cara meningkatkan fibroblas, membentuk sel-sel limfosit, meningkatkan fagositosis terhadap tumor/ kanker (Windono dan Parfati 2002)

Beberapa penelitian melaporkan sediaan rimpang temu putih mengandung flavonoid dan kurkumin yang merupakan senyawa polifenol bersifat sebagai antioksidan atau penangkap radikal bebas. Sifat ini bermanfaat sebagai pencegah kerusakan jaringan (inflamasi) maupun kerusakan DNA yang merupakan inisiasi pada proses karsinogenesis (Heim et al. 2002).

Berdasarkan uraian diatas, maka dilakukan penelitian tentang efek pemberian temu putih (Curcuma zedoaria) terhadap kualitas susu sapi perah penderita mastitis subklinis.

\section{METODE}

Penelitian dilakukan di Peternakan sapi perah rakyat Bogor dan uji kualitas susu dilakukan di Laboratorium Ternak Perah Institut Pertanian Bogor. Ternak yang digunakan adalah sembilan ekor sapi peranakan Fries Holland laktasi ke-2 sampai ke-4 dengan bulan laktasi normal (bulan ke-3 sampai ke-5) yang menderita mastitis subklinis $(++)$, dengan produksi susu ratarata10-11 1/hari/ekor. Sapi-sapi tersebut dikelompokkan kedalam tiga kelompok perlakuan. Masing-masing perlakuan diulang sebanyak tiga kali.

Rancangan yang digunakan dalam penelitian ini adalah rancangan acak lengkap 3 perlakuan dan 3 ulangan, dengan perlakuan dosis pemberian serbuk simplisia temu putih yakni Kontrol = tanpa pemberian serbuk simplisia temu putih, $\mathrm{P} 1=0,02 \%$ bobot badan dan $\mathrm{P} 2=0,04 \%$ bobot badan. Pemberian temu putih dilakukan bersamaan dengan pemberian konsentrat pada ternak, dengan cara mencampurkan serbuk simplisia temu putih kedalam konsentrat, pemberian dilakukan dua kali seminggu.

\section{HASIL DAN PEMBAHASAN}

\section{Pengaruh Perlakuan Terhadap Kadar Lemak Dan Protein Susu}

Manfaat suatu pasokan nutrient pada pakan dianggap berhasil jika memberikan dampak fisiologis dan produksi yang menguntungkan baik untuk ternak maupun pemeliharanya.

Data pengaruh perlakuan terhadap kadar lemak dan protein susu dapat dilihat pada Table 1.

Analisa keragaman pengaruh perlakuan terhadap kadar lemak susu pada penelitian ini tidak berbeda nyata $(P>0,05)$ berarti perlakuan tidak mempengaruhi kadar lemak susu. Kadar lemak susu sebagian besar dipengaruhi oleh berbagai faktor antara lain jenis ras sapi penghasilnya, tingkat laktasi, interval pemerahan, umur dan lingkungan.

Pemberian temu putih pada ternak sapi perah penderita mastitis memberikan pengaruh kadar lemak tertinggipada $\mathrm{P} 2$, dan terendah pada P1. Berbeda dengan penelitian Nurdin (2006) yang menyatakan bahwa pemberian bunga matahari berpengaruh terhadap kadar lemak susu. Dalam hal ini bunga matahari adalah tanaman yang mengandung flavonoid sebagai antioksidan demikian juga halnya dengan temu putih adalah tanaman obat yang mengandung flavonoid yang sangat diharapkan sebagai antioksidan (Sumarni,2006). Tingginya kadar lemak susu tergantung ketersediaan precursor pembentuk lemak susu, dimana precursor utamanya adalah asam asetat dan betahidroksi butirat.

Tabel 1: Pengaruh perlakuan terhadap kadar lemak dan protein susu (\%)

\begin{tabular}{ccc}
\hline Perlakuan & Kadar Lemak & Kadar Protein \\
\hline Kontrol & $3,384 \pm 1,231$ & $3,36^{\mathrm{a}} \pm 0,32$ \\
P 1 $(0,02 \% \mathrm{bb})$ & $3,191 \pm 0,928$ & $2,97^{\mathrm{b}} \pm 0,43$ \\
P $2(0,04 \% \mathrm{bb})$ & $3,435 \pm 0,898$ & $3,43^{\mathrm{a}} \pm 0,46$ \\
\hline
\end{tabular}


Keterangan. Angka yang diikuti oleh Superskrip yang berbeda menunjukkan perbedaan antar perlakuan $(\mathrm{p}<0,05)$

Hasil penelitian ini membuktikan bahwa penambahan $0,002 \%$ x bobot badan dan 0,004 $\% \mathrm{x}$ bobot badan tepung temu putih selama 2 bulan belum mampu mempengaruhi kualitas lemak susu sapi penderita mastitis subklinis.

Kondisi MSK pada ternak turut berperan dalam mempengaruhi komposisi susu. Peningkatan jumlah sel somatik memberikan efek negatif terhadap kadar lemak susu. Jumlah asam lemak terbang meningkat dan aktivitas enzim lipase yang dihasilkan oleh sel somatis mengakibatkan ketengikan dan penurunan kualitas produk susu (Sudarwanto et al. 2006).

Analisa keragaman pengaruh perlakuan terhadap kadar protein pada penelitian ini berbeda nyata $(\mathrm{P}<0,05)$. hasil uji lanjut menunjukkan bahwa P1 berbeda nyata dengan Kontrol dan P2. Hal ini sejalan denganhasil penelitian Nurdin dan Susanty (2009) yang menyatakan hasil uji invitro penggunaan $2 \%$ temu putih dalam kosentrat memberikan pengaruh kandungan $\mathrm{NH}_{3}$ tertinggi. $\mathrm{NH}_{3}$ rumen dibutuhkan untuk mendukung petumbuhan mikroba rumen yang mempunyai andil dalam sintesis protein. Peningkatan protein susu dimungkinkan terjadi karena tersedianya bahan baku sintesis protein susu yaitu asam amino. Asam amino merupakan precursor utama pembentuk protein susu. Secara keseluruhan rata-rata kadar protein susu pada penelitian ini memenuhi syarat mutu susu segar yang ditetapkan SNI (2011) yaitu minimal $2.7 \%$.

Kadar protein susu merupakan komponen yang mudah berubah dan mempunyai arti penting dari segi nutrisi. Perombakan protein dapat terjadi pada susu yang berasal dari kwartir penderita mastitis maupun mastitis subklinis, karena keberadaan enzim proteolitik. Plasmin meningkat dua kali lipat selama mastitis yang berasal dari sel somatik yang dapat menyebabkan kerusakan kasein. Kerusakan Protein susu akibat mastitis dapat terus berlangsung selama pemrosesan dan penyimpanan susu (Jones 2009).

\section{Pengaruh Perlakuan terhadap bahan Kering (BK) dan bahan kering tanpa lemak (BKTL) susu}

Data pengaruh perlakuan terhadap bahan kering dan bahan kering tanpa lemak dapat dilihat pada Table 2 .

Rata-rata kadar bahan kering susu pada penelitian ini berkisar antara 12,012\% sampai dengan $12,47 \%$. Rendahnya kadar bahan kering susu pada perlakuan P1, seiring dengan tingginya produksi susu pada perlakuan P1, dengan kata lain produksi susu yang dihasilkan pada penelitian ini memiliki kandungan air yang tinggi pada perlakuan P1, dapat dibuktikan dengan rendahnya kandungan bahan kering yang didapatkan selama penelitian pada perlakuan P1.

Kadar bahan kering tanpa lemak (BKTL) diperoleh dari hasil pengurangan kadar bahan kering susu dengan kadar lemak susu (Sanjaya, 2009). Protein dan laktosa merupakan komponen terbesar BKTL. Bahan kering tanpa lemak dipengaruhi oleh beberapa factor diantaranya komposisi susu (protein, lemak, laktosa dan mineral) (Sudono et al. 2003). Banyak yang mempengaruhi BKTL diantaranya suhu lingkungan, masa kering kandang, nutrisi, dan masa laktasi (Schmidt, 1971).

Hasil pengamatan selama penelitian kadar BKTL berkisar antara 8,81\% sampai dengan 9,03\%. Analisa keragaman pengaruh perlakuan terhadap bahan kering tanpa lemak memberikan hasil yang berbeda nyata $(\mathrm{P}<0,05)$. Untuk mengetahui perbedaan antar perlakuan dilakukan uji lanjut. Hasil uji lanjut memperlihatkan bahwa perlakuan P1 berbeda nyata dengan control dan perlakuan $\mathrm{P} 2$.

Tabel 2. Pengaruh Perlakuan terhadap BK dan BKTL susu (\%)

\begin{tabular}{ccc}
\hline Perlakuan & BK & BKTL \\
\hline Kontrol & $12,47 \pm 1,432$ & $9,03^{\mathrm{a}} \pm 0,35$ \\
P $1(0,02 \% \mathrm{bb})$ & $12,012 \pm 1,112$ & $8,81^{\mathrm{b}} \pm 0,33$ \\
P $2(0,04 \% \mathrm{bb})$ & $12,416 \pm 1,105$ & $9,01^{\mathrm{a}} \pm 039$ \\
\hline
\end{tabular}


Keterangan. Angka yang diikuti oleh Superskrip yang berbeda menunjukkan perbedaan antar perlakuan $(\mathrm{p}<0,05)$

Jika dilihat dari nilai minimal BKTL adalah $8,81 \%$ masih memenuhi Standar Nasional (SNI) 01-3141-1998 tentang syarat susu segar khususnya BKTL yaitu sebesar 8,0 \% .

Protein dan laktosa merupakan komponen terbesar BKTL, perubahan kadar protein susu mengakibatkan perubahan kadar BKTL. Susu yang berasal dari sapi perah penderita MSK mengalami perubahan total protein tidak tinggi, tetapi terjadi penurunan persentase kasein sementara whey protein meningkat. Selain kondisi MSK banyak yang mempengaruhi BKTL diantaranya suhu lingkungan, masa kering kandang, nutrisi, dan masa laktasi (Soedono et al. 2003).

\section{KESIMPULAN DAN SARAN}

Berdasarkan hasil penelitian ini dapat disimpulkan bahwa pemberian temu putih (Curcuma zedoaria) terhadap sapi perah penderita mastitis subklinis sebesar 0,04\% bobot badan memberikan pengaruh yang nyata terhadap kadar protein dan BKTL susu, namun belum mempengaruhi kadar lemak an BK susu yang dihasilkan. Kondisi mastitis Subklinis erat kaitannya dengan daya tahan tubuh ternak, untuk itu perlu dilakukan penelitian lebih lanjut, untuk menentukan respon fisiologis daya tahan tubuh ternak penderita mastits subklinis dengan penggunaan temu putih (Curcuma zedoaria).

\section{DAFTAR PUSTAKA}

Badan Standarisasi Nasional. 2011. Standar Nasional Indonesia (SNI) Susu Segar No. 01-3141-2011.

Heim KE, Tagliaferro AR, Bobilya DJ. 2002. Flavonoid antioxidants: chemistry, metabolism and structure-activity relationships. J Nutrl Biochem 13(10): $572-584$

Hurley W.L. 2009. Mastitis case studies, Milk Composition and Quality. http://classes.ansci.illinois.edu/ansc438/ mastitis/mastitisresources.html. $[4$ Desember 2010
Jones GM. 2009. Understanding the Basics of Mastitis. Virginia Cooperative

Extension. Publication 404-233. http://pubs.ext.vt.edu/404/404-233/404233.html. [22 Februari 2011]

Langford FM, Weary DM, Fisher L. 2003. Antibiotic Resistance in Gut Bacteria from Dairy Calves: A Dose Response to the Level of Antibiotics Fed in Milk. $J$ Dairy Sci 86(12):3963-3966

Nurdin E. 2006. Pengaruh Pemberian Bunga Matahari dan Bioplus terhadap Produksi Susu dan Efisiensi Ransum Sapi Perah FH. J Agrisistem 2;59-62

Nurdin E. 2007. Pengaruh Pemberian Tongkol Bunga Matahari dan Probiotik terhadap Penurunan Derajat Mastitis pada Sapi Perah FH penderita Mastitis Subklinis. $J$ Pengemb Pet Tropis 32(2);76-79.

Nurdin E, Susanty H. 2009. Efek pemberian bahan antioksidan alami terhadap produksi dan daya tahan tubuh sapi penderita mastitis subklinis. Laporan Penelitian Fundamental.

Sanjaya AW, Sudarwanto M, Lukman DW, Purnawarman T, Latif $\mathrm{H}$, Soejoedono RR. 2009. Penuntun Praktikum Hygiene Pangan Asal Hewan. Bagian Kesmavet, DIPHK, Fakultas Kedokteran Hewan IPB.

Schmidt GH. 1971. Biology of Lactation. Freeman and Company. San Fransisco.

Shem MN, Malole, Machangu R, Kurwijila LR, Fujihara T. 2000. Incidence and Cause of Sub-clinical Mastitis in Dairy Cows on Small holder and Large Scale Farm in Tropical Area Of Tanzania. Asian-Aust. J Anim Sci 14(3);372-377.

Soedono A, Rosdiana RF, Setiawan BS. 2003. Beternak Sapi Perah Secara Intensif. Agromedia Pustaka, Jakarta

Sudarwanto M, Latif H, Noordin M. 2006. The Relationship of The Somatic Cell Counting to sub-clinical Mastitis and to Improve Milk Quality. $1^{\text {st }}$ International 
AAVS Scientific Conference. Jakarta, July 12-13, 2006.

Sumarny R, 2006. Karakteristik Kimiawi, Aktifitas Antiproliferasi Sel Lestari Tumor dan Aktifitas Fagositosis secara in-vitro dari Fraksi Bioaktif Rimpang Temu Putih [Curcuma zedoaria
(Christm) Roscoe]. Disertasi. Sekolah Pascasarjana Institut Pertanian Bogor, Bogor

Windono T, Parfati N. 2002. Curcuma zedoaria (Bergius) Roscoe: Kajian Pustaka dan Aktivitas Farmakologik. Artocarpus 2(1):1-10 